\title{
Theoretical and Conceptual Issues on Covid-19 Pandemic
}

\author{
Etim O. Frank PhD \\ Dept of Political Science/Public Administration \\ Faculty of Social Sciences \\ University of Uyo, Akwa Ibom State \\ E. E. Ubeng \\ Dept of Political Science \& Public Administration \\ Faculty of Social Sciences \\ University of Uyo, Akwa Ibom State
}

Received: Aug. 17, $2021 \quad$ Accepted: Sep. 22, 2021 Online published: Nov. 22, 2021

doi:10.5296/jpag.v11i4.19240 URL: https://doi.org/10.5296/jpag.v11i4.19240

\begin{abstract}
The study set out to evaluate the theoretical, empirical and conceptual issues on COVID-19 Pandemic. It stated that the American system is described as a liberal capitalist system, which theoretically operates upon private ownership of the means of production, pursues profit in business trading as the motivation and production are for the markets. In this system, price mechanism determines demand and supply. China on the hand, had started reforms where they transited from Communism to Socialist market economy with strong State -OwnedEnterprises driving the economy. They have acquired the capitalist ethics of profit and competition hence aiming at profit in the global market place. In the course of this, they obtained favorable balance of trade with the U.S. The former U.S. president was desirous to change the situation, and started a trade-war with China which negotiations failed. In the midst of this came COVID-19, which this study termed the third World War given the fact that the number of nations and casualties caused by COVID-19, is greater than both the first and second World Wars. The study applied the descriptive research technique and deployed the Elite theory and the political economy perspective of analysis. It alluded to the logic of competition in capitalism which operates in both systems as accounting for the COVID-19 as ammunition to outwit one another. It outlined the manifest and latent manifest outcomes of
\end{abstract}


the COVID-19, showing the various military ships in which their occupants were infected by COVID-19 after participating in the $7^{\text {th }}$ CISM world Military games in Wuhan,-China. It also listed a number of Cruise-Liners which were docked because the occupants were infected by the virus. It concluded that just as global alliance helped to resolve the World wars and previous pandemic, global solidarity in finding out where and how the virus started and conduct research to find potent vaccine to end the pandemic is the solution to covid-19, else mankind would live with it.

\section{Introduction}

It would seem that occasionally in human history that an epidemic of infectious disease would spread across a large region affecting a substantial number of people and bringing-forth a new way of social engagement in the society. One of such was the Spanish flu, better known as the '1918 influenza'. In recent time in 2012, came the 'Middle East Respiratory Syndrome (MERS-CoV), said to be caused by virus transferred from camel to human beings and then the SARS before we now have lately, the COVID-19 originating from Wuhan in Hubei Province of China. This has already set its new normal of wearing face mask and social distancing between discussants, getting vaccinated, avoiding crowds, wash your hands often, cover coughs and sneezes, clean, disinfect and sanitize your hands with alcohol based sanitizer.

Whether Covid-19 is a natural occurrence or not, the political events in both China and the USA which preceded it tainted it with political coloration. First, former President Donald Trump as a candidate of his political party had a political campaign slogan, 'Make American Strong Again'. He had condemned all trade agreements which past administrations in America had entered as making America weaker in trade with all other nations in the various economic agreements which existed on assumption of office as the President. He promptly dissolved some of this trade covenant such as the North American Free Trade Agreement (NAFTA) signed January 1, 1994, by Canada, Mexico and the United States. He removed trade barriers between these states. In the same spirit he argued that the American trade agreement with China was flawed, hence the loss of numerous American manufacturing companies and intellectual property to China. The then Mr. Donald Trump (as he was then known) promised to make a better deal with China when elected. On becoming the President he set for himself the task of reversing the huge trade imbalance between the USA and China. According to Hass and Abraham (2020), an agreement was struck with China which included Chinese commitment to purchase additional \$200 billion of American goods above the 2017 level by the end of 2021, however, China reneged and the status-quo remained.

He then declared China a currency manipulator, sought to confront China on intellectual property, and forced technology transfer, end China's use of export subsidies, lax labor and environmental standards, lower America corporate tax rate to make USA manufacturing more competitive (Hass \& Abraham 2020). The stage for the trade war was laid by Trump's undiplomatic approach.

Conceptually, James Chen (2021) had averred that trade-war happens when one country retaliates against another by raising import tariffs or placing other restrictions on the other 
country's imports. Trade-war can commence if one country perceives that a competitor nation has unfair trading practices. It would be recalled that the 1930s Great Depression of the global economy was as a result of trade-war. The United States had enacted the famous 'Smoot-Hawley Tariff Act' to protect American farmers, thereby making agricultural goods from UK/Europe expensive compared to that of the USA. Several European nations reacted with corresponding higher tariffs. Trade declined, income fell and business was dull, most economies based on agriculture stagnated. The cumulative effect was the Great Depression of the 1930s. There are side effects of protectionist policies which are controversial. It protects national interests and provides advantages to domestic businesses. However, it may ultimately hurt local companies, consumers and the economy. The intention of former President Donald Trump were to protect domestic economy from unfair competition, increase demand for domestic goods, promote local job growth, improve trade deficits and punish China which he accused of unethical trade policies. He then imposed tariffs on goods from China who reacted with 25 per cent tax on over 100 U.S products.

The opportunity came to make the relationship much better through friendly games. It is important to note that since $776 \mathrm{BC}$ when the Greeks introduced and held the first Olympic games, the world had adopted it as the basis of global friendship through sporting events (Frank, 2015), every social group has incorporated sports into their program, not only as a form of relaxation from routine practices, but also as a means to making friends. The seventh world military games provided the opportunity to resolve the situation between the two leading economies in the world rather than aggravate it.

The global military organization also incorporated sport into the military organization and meet occasionally in what became the International Military Sports Council (CISM) every four (4) years purely for friendship making and to lessen world tension between them. The 2015, $6^{\text {th }}$ CISM games were held in South Korea, after which China won the bid for 2019. The $7^{\text {th }}$ (CISM) International Military Sports Council was accordingly hosted by China in Wuhan, after which the global pandemic occurred. The situation has generated several inquisitions some of which included, what accounted for Corona virus at the time when the global communities were gathered there? What did China do correctly to contain the spread of the virus which other nations did not do? How did China recovered early enough so as to send aids to other countries? Why did the American economy become one of the worst affected by the corona virus pandemic? This study would provide theoretical understanding and explanations to these inquests. We posit herein that this is the crisis of global capitalist system struggling for dominance.

Edwards, Reich and Weisskopf stated that the logic of capitalism rest on the necessity to find markets for expanded production constitute one of the most fundamental characteristics of capitalism. Competition induces capitalists to expand sales and production of goods in order to realize profits. Greater output leads to expanded profits and capital accumulation, but in order to realize profits on the newly accumulated capital, even greater sales of output are required. The pressure to find new buyers...leads to militarism as a means of justifying immense arm sales; and leads to imperialism, as capitalist attempt to find new markets abroad (1972 p.98). This is the nature of the American system of economic production and 
distribution which have been described as a 'free-market system. The Chinese's system was known as the Communism, before it started opening up to receive Foreign Direct Investments (FDIs) made up mainly of American capital the regime which introduced this started with Deng Xiaoping. It is currently termed a 'Socialist market Economy' wherein there are dominant State-Owned- Enterprises with private ownership of businesses. These two systems have been in opposition with each other right from the days of Adam Smith (1723-1790), through that of Karl Marx, (1818-1883). The major differences being that since men were born free with inalienable rights, which include economic rights, no one should take these rights away from them including the rights to produce whatever he is capable and sell at any price considered satisfactory to buyers by price mechanism, within the ambit of the law (Free market economy). On the other hand, the Socialists and Communists, adherents averred that the creator gave the common-wealth to all men in common, allowing the freedom of expropriation would keep the weak and disable away from accessing the commonwealth because of the strength and unbridled appetite of the bourgeoisie or capitalist elements. The struggle by the powerful bourgeoisie would debar many from accessing the wealth of the state. Thus, the state should take control of the common patrimony and distribute to all according to his need and capacity, else some would be discounted from accessing the commonwealth. In this way, the needs of everyone would have been met (Socialism/Communism).

These two economic ideas have ruled the world from inception of modern civilization and have accounted for many of the global conflicts. It had caused balance of power structure, dismembered the global community into ideological camps and continued to cause friction between the states that are adhering to any of these modes of economic organization. These ideas remotely precipitated World Wars I \& II and of course sustained the cold war until 'détente' came to ameliorate the situation.

The propositions of this study are that the observable contest between these two economic systems was accountable for the COVID-19 pandemic in 2019. This was ab initio the position of this work, to be elucidated through the enunciation of the theoretical foundation of the economic systems, described the empirical characteristics of the main political actors and connect it to the COVID-19 as an instrument of economic warfare, hence COVID-19 is herein tagged the Third World War. We embarked on relative linkages of the situation to that which laid the premise for earlier global wars. We also posited that the immediate and remote causal factors of the past global wars were basically economic just as in this case.

The broad objectives of the study therefore could be summed to establish the fact that COVID-19 came amidst economic confrontation between America and China; it must have been use as the ammunition of the trade war by one of the disputants against the other. To illustrate that between these two countries was a trade war, intended to reverse the colossal trade deficit which one had incurred against the other.

To establish that beyond the two major gladiators, all other countries which have suffered as a result of this, constituted collateral damages, just as there were in the I and II World Wars. Finally, that the global communities require alliance and cooperation in research and 
development to overcome COVID-19, just as this was the case between the Allied and Axis powers to halt World War II.

\section{The Problem}

The $7^{\text {th }}$ International Military Sports Council (CISM) event, known as the military games, took place in October 2019 in Wuhan, Hubei province of China. 140 nations participated, with 9,308 athletes in attendance in 316 events in 27 sports. Before this event China had hosted the 2019 International Basketball Federation (FIBA) World Cup, organized by the Military Sports Commission of China. All the athletes were accommodated in the Chinese Games Village. China's delegation to the games consisted of 553 participants and 230,000 volunteers to assist in the smooth operation of the events. It was later realized that in that province and particularly in Wuhan, people had been infected by the virus, raising suspicion that almost all the athletes must have returned home with a stain of the virus to spread in their various countries. This must have accounted for the rapid spread of the virus around the world. China did not alert the world immediately and did not also inform the world what it did to contain it at home. It was critical to note that International Federation of World Basket Ball (FIBA) world cup had been hosted in Wuhan, without any incident of - COVID-19. However, amidst the trade-war COVID-19 might have become the ammunition of the conflict.

Also given that earlier there was SARS, then the - FIBA games with no incident of infection, it further heightened the suspicion of COVID-19. How did COVID-19 emerge in the same locations where FIBA participants had been without an issue? The problem is that the virus has halted almost every business in the world and caused so much human disaster. The other aspect of this was that China which first experienced it, had - evolved ways of containing and dealing with it, yet it was not forthcoming with modalities on how to contain the virus, thereby letting every other nation-state to initiate its mode of containment. The muddling through approach by nation-states had - resulted to very many avoidable fatalities and still counting in many countries. Howbeit, that China's economy was fast in recovering from the pandemic to the extent that she was now sending medical supplies and assistance to other countries? What are those protocols and remedial medical-feats that China had taken which contained the spread of the virus among its citizens? It would be reasonable to assume that China and the USA quest to lead the global economy could be the rational for either of them to have used the pandemic to neutralize the other.

The empirical observations which precipitated the mindset that their trade-war accounted for the situation were; (i) over the years, the Chines communist system started limited liberalization of its economy. (ii) Consequently, many American manufacturing companies went there to establish, manufacture and freight their goods into America and still made huge profits. (iii) The situation led to loss of jobs in the America and economic boom in the Chinese economy. (iv) The situation automatically created a continuous balance of trade deficit in favor of China against America.

The desire to reverse trade imbalance on the one hand, and sustain trade advantage on the other, between the two nations was made into political slogan by the then Presidential 
candidate Donald Trump, to 'Make America great Again' through reducing the trade deficit and signing trade deals that would generate greater advantages to the USA. The former President Trump sought a review of almost all trade agreement with America and abrogated some. In the case of China, he had during his political campaigns for the office of the president, alleged that China was engaging in act inimical to competitive international trade such as subsidizing exports. These utterances and many others, hurts diplomatic relations, and cultural exchange between the two political and economic super powers, and set the stage for doing anything that may cause the other to capitulate for a monopoly to emerge.

Another dimension of the problem was that American capitalist system is in opposition to the Chinese Socialist Market Economy. The motivation to capture profits leads the capitalist firms to produce huge quantities of goods for sale on the market it think it can sell them (Edward etal, 1972 p.100). Though the capitalist tout perfect competition, in reality it seeks to eliminate a stiff competitor. This was what might have happened between China and the USA in the quest to eliminate the other via the use of COVID-19. America under the former President Donald Trump referred to coronavirus as 'China's virus', conversely China asked what American contingent to the games came for without winning a medal. This is the situation in which many others who participated in the games became carriers of the virus around the world causing collateral damages referred herein to as the third world war III. The study therefore sought to establish the theoretical background to this problem.

\section{The Approach}

In order to accurately and technically understand the issues, it was approached from the descriptive perspective. Ndiyo stated that this design sought to obtain information concerning the current status of phenomena and is directed towards determining the nature of a situation as it exists at the time of the study. The aim was to describe, what exists with respect to the variables in a situation and specify the nature of a given occurrence (2005 p.70). The main thrust of the approach was to collect data for the purpose of describing, interpreting existing conditions, practices and provide meaning to it. To these ends, it requires clear formulation of the problem. It is important to note that case studies and observations are components of descriptive procedures, which were all brought to bear in obtaining data for this study. In this particular study, the personality and character sketches of the major actors were also triangulated into the procedure of interpreting the phenomenon.

The case study inquest revealed that former president Trump won in 2016 partly because of his focus on trade reforms specifically with China. But longstanding economic theory averred that in a trade war both the home country and the foreign country roughly equally bear the cost of tariffs. Tariffs raise costs for consumers and producers in the importing country (Gagnon, 2018). After the U.S. imposed tariffs of about $\$ 250$ billion worth on Chinese import, China retaliated in 2017, the U.S. pulled out of the Trans-Pacific Partnership, thereby losing the opportunity to mobilize many other nations (Australia, Brunei, Canada, Chile, Japan, Malaysia, Mexico, New Zealand, Peru, Singapore, and Vietnam) to cause China to effect some changes in her trade policy and operations. The tariffs imposed on each other by U.S. and China was in violation of World Trade Organization (WTO) guidelines on the protection 
of one's economy.

The direct personality reading of former president Donald Trump showed that his thought and social behaviors within the context of this study, was assertive and very often impulsive and ride on populist and protectionist policies often couched in nationalist policies. These were wrapped into the slogan 'Make America Great Again'. Consequently, several misleading statements from him were accepted by his followers as truth. He had worked assiduously hard to abrogate the Affordable Care Act (aka Obama-Care). He then wanted to reverse the extensive trade-deficit with China. The failure to cause China to change the pattern of international trade with the U.S. resulted to several anti-China actions some of which included; visa restrictions to Chinese students, trade sanction on Huawei Chinese telecommunication giant and many undiplomatic statements on China.

The Chinese president on the other hand, information on him is very scanty, he is however a reformist in the Chinese Communist Party. He introduced the concept of strong State-Owned-Enterprises (SOEs) existing along with private ownership making it a 'Socialist Market Economy'. He is following the footsteps of Deng Xiaoping and Mao Zedong. He pursues deeper market reforms and restrictions on individual political freedom. Xi Jinping is a cautious and calculative Chinese leader with an eye on both economic and political leadership. He has removed term limit on his leadership. He joined the International Monetary Fund (IMF) to globalize the Chinese currency and warned that nobody 'can dictate to the Chinese people'.

All these taken together, indicated unilateral retaliatory trade actions herein termed trade war. In the midst of all these, came the COVID-19 which we herein conceptualized as the ammunition probably utilized in the conflict. The observation of the situation, led the study to draw the inference that the extensive trade deficit in favor of China, and the desire by former President Trump to 'Make America Great Again' by reversing the situation has led to a Trade war between these two countries. This manifested in the tariffs and retaliatory tariffs imposed on each other in violation of the WTO guidelines.

\section{Review of Literature}

In order to draw from existing works to position the current one, the study reviewed related works on the subject-matter. Chuan He etal who reviewed 'the effects of the US-China trade war on firms' vacancy postings', averred that there is reciprocal tariff increases between the USA and China. However, by mid-2019, the average tariff imposed by USA had risen to about 23 percent on almost all categories of products. China in return imposed about 15-30 percent of import duty on goods from the USA. The effects of the trade war they observed ranges from 'supply chain disruptions, higher prices and increased economic uncertainty as well as dysfunctional investment climate, and reconsideration of labor demands. The situation often leads to trade diversions.

Boylan etal (2021), posited that the economic nationalism, subsumed in former President Trump's regret of the trade imbalance in favor of China accounted for the trade war which was compounded by COVID-19. They reference of Owoye (2020) that the retaliatory trade 
war may have contributed to the emergence of COVID-19. It is instructive to note that COVID-19 occurred two months after the first trade deal between USA and China. It is suspected that the agreement may have become moribund.

Chuan etal and Boyland etal (2021) both made insight into this study. They both shared the position that the trade war between the two giant's economies might have accentuated the pandemic. They however failed to declare it as a third World War as upheld in this study. The cited works also did not see the trade war as an outcome of the 'protestant ethic and the spirit of capitalism', wherein perfect competition is touted by the capitalist when they actually prefer monopoly to have the market to their products. They indeed affirmed many of the positions canvassed in the study without stating the dimension of this work. Consequently, this current study have extensive gap to fill.

\section{The Analytical Framework}

The phenomenon of this study was better understood when we viewed it from both the elites and the political economy framework respectively. This was because beyond President Donald Trump there was also the Republican Party and its hordes and Xi Jinping. Elite theory (Vilfredo Pareto 1818-1923, Roberto Michels 1875-1936, and Gaetano Mosca 1858-8) posited the inevitability of a small governing group emerging in society, whatever the ideology to pursue what initially amount to their own their own selfish interests, but which may eventually benefit the entire society. Mosca referred to the elites as the political class or the numerical minorities with superior organizational skills, who rule and define public policies according to their preferences. Robert Michel's, embedded this, in his 'Iron law of Oligarchy. Joseph Schumpeter (1883-50) drawing from the classical philosophy of Plato acceded to this view, however the elites preferences are made to appear in practice as a rule on behalf of the people, whereas it is in the vested interest of the elites (Igwe, 2005 p.133). Consequently, both former President Donald Trump and Xi Jinping could have been acting in the business interests of elites of both the Republican Party and the Politburo of the Chinese Communist Party respectively.

Closely linked to this perspective is the Political Economy Perception which was described by Mclean and McMillan (2003 p. 415) as the political aspects of economic policy-making, public management of the affairs of the state. It has been described as the reciprocal influence of economics and politics, the basis and political element of the superstructure which inevitably involves attentions to relations of production and the iniquities and imbalances in the national and global distributions of economic and political power. Political economy an obvious reality, namely the economic basis of the political behavior of states and people (Igwe, 2005 p 333).

The adopted perspective of analysis brought to the fore the following issues; that indeed in every political system, there is always a minority constituting the governing class which rule over the majority of the citizenry; whether these minority ruling class do have preferences or not, their preferences are often presented as public policies to achieve public interests. The occupants of the political realm are politicians who would want things to go their ways. Thus, in America, the situation was not in favor of the political actors, coupled with the personality 
of the main actor, hence the resort to unilateral actions which vitiated the World Trade Organization's guidelines that could be applied against a competitor. This would only result in commercial conflict.

The appropriateness of the two perspective of analysis utilized in the study rest on the conjecture that decision-making structure which belong to the political superstructure, determine the economic arrangement and inputs. Thus, it is the political realm that determine what goods and services are produced and in what quantities and how to distribute the goods and services in the economy. They also direct the pattern of both domestic and international trade. The political realm in this case was directing the trade or commercial war.

Earlier in this discourse, we averred that COVID-19 is the outcome of the challenge of economic and ideological warfare which we referred to as the third world war. The operating economic system in America is liberal capitalism based on individualism and is driven by profit motivation. It is based on competition of all which induces capitalism to expand sales and production of goods in order to realize profits. Greater output leads to expanded profits and capital accumulation but in order to realize profits on the newly accumulated capital, even greater sales of output are required...it leads to militarism as a means of justifying immense arms sales; and it leads to imperialism, as capitalist attempt to find new markets (Edwards, etal 1972 p.98). The motivation to capture profits leads the capitalist firm to produce huge quantities of goods for sale on the market if it thinks it can sell them (Edwards, etal 1972 p.100). As Paul Sweezy (cited in Edwards, etal 1972 p.135) said the primary function of the capitalist state is to defend capitalist institutions and practices. The state goes all out to defend the economic system and its institutions.

The capitalist system operates on certain principles which are; perfect competition, market economy, private property and legal relations of ownership, private ownership and control of the means of production and the ethics of 'Homo Economicus' that is, the most important method of increasing an individual's happiness and welfare is by increasing how much money he has or earns. No matter how happy one is now, one would be happier with more income (Edwards, 1972 p 91). The popular cold war which created the famous 'iron curtain' was but an ideological conflict to protect capitalism on the one hand, and communism/socialism on the other...

Empirically, we have seen how capitalism had penetrated Russia until 'Glasnot and Perestroika' came to be in the 1990s which later led to the crumbling of the union, with China remaining the last bastion of communism, it is very suspicious of engagement with the USA. In real terms, capitalism does not tolerate competition; it would rather exterminate a competitor for a monopoly. This is what might have happened between the USA and China with coronavirus (COVID-19) serving as the ammunition.

It is instructive to note that the USA had often played the role of a global leader since the end of the Second World War on most issues of global dimension. This had often brought her into conflict to promote free market economy. However, coronavirus (COVID-19) would remain almost the first issue which the USA took the back seat in the early pursuit for the solution, and later became a major casualty. 
Also it should be noted that China's actions on a global scale and its potential as a world leader serve as a challenge to USA global hegemony. Though some have argued that China's embrace of capitalism is no threat to liberal democracy. Andrei Lungu (2021) had observed that US-China is engaged in an intense long term rivalry and that ideology informed Beijing-Washington's dealings. Deng Xiaoping created the 'détente' (easing of hostility or strained relations between countries) but this was never fully appreciated by the Chinese Politburo.

In the past as stated earlier there were SARs, MERs though they spread, they did not affect very significant portion of the global community and economy adversely. However, when the rivalry between U.S. and China was almost at its peak wherein China was having trade surplus and America deficit, coupled with the intention to 'Make America Great Again' COVID-19 surfaced. It came when American contingent joined others in Wuhan. The American leader at the time lived in self-denial of the entire Center for Disease Control (CDC) daily briefings. The American economy became closed with partial production where it was possible.

It would be recalled that the First World War erupted in 1914 and had 32 nation-states involved in the warfare against Nazi Germany, and the Axis power, it ended with about 16 million causalities. The belligerent Axis forces against the Allied cluster brought Sir Winston Churchill on board, who activated an economic strategy while the Royal Navy activated economic blockade to starve the Axis forces of essential supplies, for the war to come to an end. The Second World War started in 1939-45 with 30 countries in the Allied camp, caused by economic interests and struggle for supremacy at the background, though arms and ammunition played significant role, it consumed about 12 million human lives. Economic instrument played more significant role in bringing it to an end against Japan and the old Axis allies Germany (Encyclopedia Britannica). Britain and America convinced Spain and Portugal not to supply 'wolfram' (a tungsten ore, used in the production of steel armor) to Germany. Spain and Portugal in turn received military protection from Britain and Allied forces against prospective attack by the Axis military coalition. It is important to note that economic factors played significant roles in both the first and the second world wars respectively.

Consequent upon the above, this study dignified COVID-19 phenomenon with the appellation of the third world war (III WW) drawn from the resources of knowledge and logic of the previous world wars. It would be recalled that in the First World War (1914-1918), 32 nations were involved, while the second (1939-1945), had 30 nations participating in it. According to Worldometer (2021), 220 Countries and territories around the world have reported a total of 191,869,905 confirmed cases of the coronavirus COVID-19 and a death toll of 4,115,864 with China having 4,636 deaths. The USA currently leads the world in the total casualty figures with 24 per cent of the global total despite having just 4.2 per cent of the world population (Ogunmupe, 2020, p 18). Worldometer database showed United States with the highest cases of death. These indicators are higher than those of the previous wars hence; COVID-19 earned the title Word War III. 
It is important to also note that all these wars have one common denominator, which is the quest for economic gains. Wars are usually caused by one country's desire to have economic advantage over the other, whatever the other reasons may be. Consequently, COVID-19 has the quest for economic advantage as its major content, this further attest to why in this study; we conceptualized the 'trade and economic war' as the third global war. The foundation of the free-market economy is located in the postulations of various political and economic theories including that of John Locke (1632-1704). He provided the most robust foundation as the father of Enlightenment and liberalism in his Two Treatises of Government. Men he averred created the institutions of government to secure their private property because life and property of the possessors were unsafe and insecure. Government was to secure the private property rights of individuals, hence the government was not permitted to regulate the prices of exchange in the market society except where in so doing, would generate clear advantage to the public. The Government, according to John Locke must regulate trade and ensures its balance. Though economic activities occurs independent of the state, he advocated a symbiosis between the two social institutions, one directing the course of the other in the society's favor. A careful study of the declaration of independence and the American constitution revealed both documents to be replete with phrases such as 'all men are created equal, life, liberty and the pursuit of happiness and so forth are culled literally from the second treatise. This is the basis of political economy and precisely what America was seeking to do in this context (Popkin, etal 1981 cited in Frank, 2015, p.128). Locke was the father of small and less costly government and he espoused all the ethos of free-market economy. The operating principles of the American economy were all drawn from Locke's treatises.

It should be clear from the theoretical foundation of 'free-market economy' that the state is free to regulate its economy to ensure it balance and secondly, as long as the interference in the economy would be in the society's favor, such interventions are permissible. These are what the American president did and the Chinese responded. It is a critical role of the state in free-market economies to defend its institutions in the interests of the citizens. The outcome when retaliated amount to economic anarchy termed trade war.

The American free market system is one which emphasizes freedom of investment and production, where 'capital' is invested and it augment itself through profit. Essentially, it is a market economy where everything is produce for exchange. The price mechanism or market forces regulate the market and allocate resources to areas of efficiency (in this context investors found China more efficient). In this market society everyone wears a commodity mask; you are either a buyer or seller. It is assumed to be a perfect market operated by market forces but there could be interventions by the state as outlined in its theoretical foundation. This is often touted as the dynamic of the system because competitors would evolve technology to undercut the market by producing at lower cost and diverting consumers to their products (Frank 2015 p.171).

This economic system seeks the elevation of the individual freedom to produce and sell anything within the bound of the law. It has been referred to as 'laissez-faire (leave alone) with less or no state interference. It is a system which is extremely detrimental to the workers 
and other employees, leaving them unprotected against the demands of their employers, were it not for trade unions (this is perhaps what American investors are enjoying in China). It is most unregulated variant of market economy where prices are determined by the forces of supply and demand (Sodaro, 2008 p. 349). In all these, competition is inherent and it is assumed to provide the dynamism of the free market economy. This is often not true in reality, what the capitalist does is seek to eliminate the competitor to have the market in order to make more profit and to save resources from Research and Development, and the lengthy processes of researches to come out with a new technology and product. This often leads to the establishment of monopoly (Frank, 2015).

The various accusations over the COVID-19 researches are very instructive. The numerous contenders have accused one another of wanting to steal other's blue print on COVID-19 vaccines, hence we have headlines such as (Coronavirus: Cyber-spies hunt COVID-19 research, US and UK warn -BBC News, US charges Chinese COVIDS-19 - research 'cyber-spies). These are familiar online headlines news in recent time. The American investors went to China for two critical reasons among others; the first being to break down the last bastion of Communism having succeeded to bring down old Union of Soviet Socialist Republic (USSR) through the introduction of 'Perestroika and Glasnot' or reforms by Michele Gorbarchev. The second was to take advantages of the favorable investment conditions in China, which allow almost complete repatriation of profits, freedom from unionized workforce, very low cost of production, available pool of skills manpower, hence the rush to invest in China. The outcome of the massive investments in China is the balance of trade in table 1 below. Following American successful penetration of the old USSR economy where restructuring and openness (Perestroika and Glasnot) of the economy was embarked upon, the economy became extensively liberalized. The attention was now on China as the last bastion of Communism to be dismantled. This has invariably resulted into favourable balance of trade with China.

In addition to already stated economic situations, the following liberal economic conditions made China an investment destination for American firms: corporate tax rate is low, 25\% lower than what is obtainable in countries very close to America, Mexico, and Brazil etc. Wage charges are very low consequent upon the huge population, the environment is one in which the investors can easily exploit the workers with absence of trade unions. China has less corruption which does not increase the cost of doing business. Transparency International (TI)-Corruption Perception Index ranked China $87^{\text {th }}$ out of 180 countries in 2018 report. President Xi Jinping had launched anti-corruption and improved on the perception index greatly. This means firms have to incur less additional cost in the line of business. It also has low crime rate and most importantly lower energy cost fixed at $\$ 0.08$ per kilowatt an hour, and there is abundant pool of skilled and unskilled labor force. These conditions lured several American firms some of which are; Apple, Starbucks, Intel, Procter and Gamble, Coca-Cola, Nike, Boeing, Microsoft, General Motors, KFC, Wahl Corporation, 3-Minnesota etc., to China to take advantages of these factors of production since it would be cheaper producing there and freighting goods into the American market. This arrangement placed the USA in a balance of payment deficit consistently. Table 1 below show a five-year trading result with 
China reaping the benefit of American foreign direct investments. 
Table 1. Summary of USA trade in goods with China 2015 -2020

\begin{tabular}{|l|l|l|l|l|l|}
\hline & Month & Exports & Imports & Balance & Remark \\
\hline 2015 & & $115,873.4$ & $483,201.7$ & $-367,328.3$ & BOTD - \\
\hline 2016 & & $115,594.8$ & $462,420.0$ & $-346,825.2$ & BOTD - \\
\hline 2017 & & $129,997.2$ & $505,165.1$ & $-375,167.9$ & BOTD- \\
\hline 2018 & & $120,289.3$ & $539,243.1$ & $-418,953.9$ & BOTD- \\
\hline 2019 & & $106,447.3$ & $451,651.4$ & $-345,204.2$ & BOTD - \\
\hline
\end{tabular}

United States Census-Foreign Trade https://www.census.gov -U.S International trade retrieved $12 / 08 / 20$ by the author *BOTD-Balance of Trade Deficit.

The implications of the persistent economic deficit with China in table 1 above are;

i) America was consuming more from China by keeping its industrial growth and employment up by American firms, while they were adding marginal economic advantages only in the American economy. (ii) Balance of trade deficit generates economic boom in China and low economic dynamism in the USA, since it keeps industrial production up in China and only consumption in the USA. (iii) It created indebtedness of the USA to China. (iv) It assists in a higher standard of living in the country with trade surplus much more than the country with trade deficit. The economic consequences of the above trade data precipitated the trade war between the two trading partners, let by former President Trump and now being continued by the current President Joe Biden.

China may have been categorized as a Communist state, however Secretary-General Deng Xiaping had exfoliated enormous reforms which had opened the economy which made it receptive to foreign capital thus; (i) The old communes had been dismantled and agricultural producers in the old communes were free to trade with excess goods produced after turning in the mandatory quota of the food supplied to the state in the rudimentary emerging free markets. This indicated the embrace of openness and restructuring. The price mechanism was introduced in the economy. (ii) The desire for faster growth led to the creation of Economic Free Trade Zone along the coastal cities, Individual and cities were encouraged to embark on foreign trade.

iii) Private sector which had been obliterated under Chairman Mao Zedong reign, crept back into the liberalized economic setting. By 2005 there were 4.4 million, private sector businesses employing over 100 million in the sector and producing over half of China's industrial output (Sodaro, 2008 p. 678). This indicated the speed and dynamism of liberalization of the economy. Inflation set into the economy as private sector pulled the economy in different directions, but it is always kept under control by the state's intervention.

The above variables presents China not as entirely Communist State, but 'Socialist Market Economy' an emerging free-market economy, which dropped the welfare and collective well-being ideas for the excessive individualism which drives the free-market though without the rule of law and organized labour unions. Chinese current president had served as acting governor of Zhejiang province where he focused on restructuring the industrial infrastructure to promote sustainable development. It is presumed he would be a hardliner against anything that would obstruct the economic development of China hence discriminating trade tariff by 
America would be resisted (Sodaro, 2008 p. 678), and in fact retaliated.

These free-market principles adopted by China made it the second highest polluter of the world from industrial emission after the USA. The World Bank has stated that about 300,000 people die in China from respiratory disease related ailment from industrial pollution. River waters particularly in the Southern coastal industrial areas are so polluted that they are not feet for irrigating farmlands. Perhaps these explain the suspected scramble for other lands by China.

The embrace of free-market comes with the protestant ethics and the spirit of competition and the desire to out-do the competitor by any means reasonable. This capitalist spirit perhaps accounts for China's Shylock's disposition in granting loans to other nations and taking 'a pound of flesh' at default. Consequent upon this capitalist ethos, loans to Sri Lanka, Papua New Guinea, Maldives, Pakistan, Malaysia, Mongolia and Republic of Kazakhstan, who have all defaulted, was followed with the takeover of these countries assets, not the projects for which the loan was procured on.

In Africa, China has extended loans to Angola, Ethiopia, Kenya, Republic of Congo, Sudan, Zambia, Cameroun, Nigeria, Ghana and the Democratic Republic of Congo (DRC). In Zambia, China has taken over their National Power Corporation and the Broadcasting Corporation of Zambia (Guardian Editorial August 11, 2020). In Djibouti, China has already set up a military base as a result of loan payment default. One thing is clear in African states; they all have poor track records in public debt repayment. Thus, China may be taking over the commonwealth of African states through loans default strategy. It is the competitive spirit drawn from the emerging free-market capitalist economy which led it into the trade war with America and would do so with anyone.

\section{The Trade War}

We had in the preceding discourse alluded to the fact that wars are often caused by the quest to control or even take over another country's economic advantages. Often reasons other than economic are usually advanced to cover the economic motive. The economic conflict was expected with anyone, given the political mantra of President Donald Trump. 'Make America Great Again' the theme of the policy thrust of the former American President while campaigning. It implied reducing the considerable trade deficit with China and other country and perhaps caused American industries operating in China to relocate to America. In this case several economic advantages associated with manufacturing in America would accrue to the local economy. It is the view of this study that his approach was wrong.

The approach as outlined by Donald Trump himself was to impose tariffs on goods imported from China. This measure was complemented by China on all the inputs brought in by American firms for their production. The outcome of that was a situation described by the Oxford English Dictionary and James Chen (2021) as 'economic warfare'. This is a condition in which one state uses measures such as discriminatory tariff on another with the primary effect which is to weaken the economy of another state for the advantage of the initiating states. It is very often meant to regulate the source of critical economic resources so as to 
enhance the operation of the intelligence activities without allowing the 'rogue state' operate freely. It is initiated to damage the economy of another state considered belligerent. It is important to note that the strategies that states put in place to increase their economic power and their impact on the international balance of power can be interpreted only by the concept of economic warfare (Harbulot, 2018).

In China there is a perception that America does not want it to rise into global economic power. The elements of the trade war included 'tariff imposed on all goods from China into America, meant to encourage Americans to buy American products by making imported goods from China very expensive in order to make 'America great again.' The United States had imposed tariff on goods from Chines worth $\$ 360$ billion, China retaliated with imposing import tariff on goods worth $\$ 110$ billion from America. January-September 2018 saw the USA imposing four different tariffs on China including 15 per cent duty on musical instruments from China, while it retaliated with 5-25 per cent tariff on US goods as well (BBC online news 2020). In all these, it is the consumers of the taxed items that would have to pay extra for them thereby reducing their expendable income and eventually lowering standard of living. The current Chinese leader came into office after his predecessor had been removed on the ground of corruption. One of his key focus areas was on improving international relations.

The current Chinese leader has consolidated power having eliminated all those alleged to be corrupt and assuming the title of 'core leader' and has had term limit abolished for him. He is one qualify as a strong leader and would rather go to war than surrender to any other power. $\mathrm{He}$ is a tough and strong leader though his appearance belies these characteristics (www.Xi Jinping accessed 25-08-20).

The other instruments of trade war are; blockade, blacklisting and preclusive purchasing control of perceived enemy's assets or supply lines. Others are discriminatory tariff, sanctions and suspension of aids, freezing of capital assets and prohibition of investments and the prevention of capital inflows. The interplay of all these in economic relations between states is but 'economic or trade war'. All of these are not being deployed in the war between these two countries safe for import and export tariffs which raise the consumer price of the products, thereby forcing consumers to go for alternative products with similar or the same utility value. The net effect is that the goods which are subject of the trade war would not trigger high demand and income for their manufacturers. In the final analyses, they may have to transfer their production lines to neighboring countries where their capital would be considered safe.

\section{Conspiracy Theory of COVID-19}

The question to ask remained, why did corona virus occur when the entire world was assembled in Wuhan? Diseases certainly do not have period of occurrence except the conditions are created. The origin of the Corona Virus has been shrouded in controversy giving room for considerable speculation as the then American President Donald Trump referred to it as 'Chinese virus', while China on the other hand speculated that it must have come from America's Biological Weapon Laboratory at Fort-Ridge, California. This 
two-ways suspicion was against the backdrop of the free trade -war which was raging between them. The Chinese allegation was premised on the empirical fact that the American contingent to the $7^{\text {th }}$ International Military Sport Council (CISM) won no medal in the competition. It follows that they must have come under the pretext of the competition to cause crisis with economic dimension. This logic could not be sustained because the industrial and commercial center of China is Shanghai, while Wuhan the epicenter of COVID-19 is not listed among the seven (7) industrial cities in China, however, this was to create the impression that it leaked from the Wuhan laboratory. The American President was desirous to upturn this trade deficit. The Chinese's further observed that in the previous $6^{\text {th }}$ CISM games in South Korea, the USA obtained two (2) gold, two (2) silver and two (2) bronze, which placed the USA at the $23^{\text {rd }}$ position on the medal table. Consequently, for winning nothing, they must have come for something other than the competition. This is however, a weak argument because not all competitors are billed to win in contests. The proximity of the Games village to the Wuhan wet Seafood market, was said to be too close, hence the vector carried the virus across to infect the athletes. This is again not a tenable position from China, since the participants in the games did not eat food from the wet market.

In order to situate these conspiracies, we elected to review SARs which preceded COVID-19. In 2003 a Russian scientist Sergei Kolesnikov asserted that SARS virus produced 'measles and mumps' which could not occur naturally (WHO, 2003). The world body started to compile its symptoms and to follow it up to understand its nature with the view of adopting clinical treatment procedures. He asserted that these diseases could only be produced in the laboratory. Tony Zeng (2003) raised the bar of the conspiracy by asserting that Americans must have created the virus because they had taken blood samples of the Chinese to study the genes responsible for the longevity of the Chinese in the 1990s. This was also not plausible because others who were not Chinese were being infected with serious consequences.

The defense lines available were; (i) before COVID 19, there was Severe Acute Respiratory Syndrome (SARS) which affected China at the level of an epidemic. It caught 8000 people with 800 dead. This did not connect the Americans in anyway. Studies in China attributed the SARS virus to bat as the reservoir. Bats are eaten in China as delicacies hence it was transferred to humans. Drawn from the above, it was reasonable and logical to conclude that the allegation that the virus was brought from America could not be tenable because a variant of it had occurred earlier in China. COVID-19 could then be a mutated variant of the earlier SARS.

The failure to find its source further convinced the people that COVID-19 could have been artificially synthesized and spread by some individuals and even governments. Circumstantial evidence suggests that SARS got to humans from Asian palm civets (civet cats) a type of animal that is often killed and eaten in Guangdong where SARS was first discovered (People's Daily, 2005, Sept 11). We are left with the proposition that the SARS virus and later Corona virus are indigenous to China, SARS had been known there and the vector being the bat before it affected the humans.

Lastly, the conspiracy theory became heightened for additional two reasons, why have the 
world medical community not subjected any of the victims to post-mortem medical analysis, to discover the internal complications caused by the Covid-19 virus which culminated into deads? Does the virus relate in any way to bacteria common to human? What kinds of viruses are accommodated in Wuhan Virology laboratory? The cradle of COVID-19 remained shrouded in mystery but it is safe to say it is indigenous to China and could have been used as weapon of the trade-war. The questions raised herein, may have accounted for the vaccine hesitance in some places.

The physical manifestation of the trade-war which used COVID-19 as ammunition is visible at both the micro and macro levels respectively. At the macro level; (i) The Wuhan CISM military games athletes were selected from the various formations of the military establishment. The ones that participated returned to their various groups, and those from the Marine Corps, rejoined their compatriots in the vessels. This was the case with ' $U S S$ Theodore Roosevelt' the American nuclear aircraft carrier commanded by Captain Brett Crozier. He had discovered that about 100 of the 400 personnel on board the vessel had contracted COVID-19 as they exhibited the symptoms enunciated by the World Health Organization (WHO). He then sought permission to dock the ship. The logic deduced from this was that those who were part of the contingent to Wuhan must have returned with doses of the virus to infect others. (ii) The crew of the French Naval Ship 'Charles de Gaulle with 40 sailors on board was also infected by corona virus. It had since docked for quarantine and treatment. The other French ship included Chevalier Paul. Some of the crew members must have been in Wuhan, else how could they have contracted COVID-19? (iii) The Belgian frigate Leopold I on March 2020, Dutch submarine HNLMS Dolphin, Taiwan's Naval ship Dunmu fleet were also affected by the virus. These empirical cases attested to the fact that the data affirmed that these crew members must have had men and women who made up the contingent to the $7^{\text {th }}$ military games, who returned with the virus to infect other crew members on board the vessels. They could not have been infected on the sea without a vector.

iv) Beyond the military ships, private Cruise-Ship -Liners were also affected. The civil populace picked it in social gatherings and spread it on board and halted their businesses as indicated by the list of cruise liners with cases of corona virus which included; World Dream, Diamond Princess, Westerdam, Grand Princess, A-Sara, Costa Magica, Braemar, Costa Lumisa, Carnival Valor, Silver Explorer, Silver Shadow, Norwegian Bliss, Norwegian Breakaway, Celebrity Solstice, Ruby Princess, MSC Bellissima, Ovation of the Seas, Voyager of the Seas, and MS Roald Amundsen among others. The limited space made it impossible to observe the WHO protocol on board the liners. Cruising had to be put on hold and maritime business affected negatively. On the other hand, if any of the contingents came with corona virus to Wuhan, why were there no occurrences of incidents of the virus in their home country before the Wuhan episode? This is not a likely source of the virus. Thus, the cradle of the virus remained Wuhan. It is also an empirical fact that all the surrounding towns and cities that are linked to Wuhan the epicenter (Shangai, Huanggang, Ezhou, and Huangpi etc.) had negligible or low incidents of corona virus, when as reported about 5million people left Wuhan before the city was shut down. They were obviously vectors of corona virus everywhere they went. It is also important to recall that there were about 300,000 volunteers 
at the game, did they not pass through the adjoining cities nor returned to their locations? There must have been precautionary measures taken to curtail it spread. At the micro level the trade war as reported by the Brookings institute have significantly hurt the American economy without solving the underlying economic concerns it was meant to resolve (Ryan and Abraham, 2020). Trade war increases the price that consumers pay for products in the domestic economy. All imported items from the country in trade war become expensive.

The outcomes of COVID-19 pandemic are that it has now earned a place in history just as the 'Flu Pandemic in the global community. What would however become of concern would be the vaccine to contain and cure it. What was certain nevertheless is that it originated from China, in the midst of 7th World Military Games, which had put all military formations which participated in the games at risk. In the affirmation of this assertion, certain questions are pertinent; were there such health challenges in China before COVID-19? The answer certainly is in the affirmative, yes-SARS-2 with some similarities.

Capitalism claimed that it operates in a situation of perfect competition, could it be that one of the free-market countries was desirous to cripple the economy of the other to create monopoly? We do not know, but it is a probability. All the countries that have taken the virus to the analytical laboratories for sequencing and vaccine development have accused each other of wanting to steal the blue-print of the vaccine from each other. Many have embarked on vaccine nationalism by not wanting to sell and donate excess out, until all its citizens must have had enough.

The issues which surrounded the subject matter are; (i) the Chinese economy of Wuhan and the nearby cities were ravaged and quickly brought to a standstill. It became an epidemic in China before becoming a global pandemic. (ii) What did China do right to get out of it and restart its economy to the extent of sending experts and materials assistance to other countries particularly in Africa? (iii) What knowledge was brought forward from the experiences of SARS -2 which had aided the containment of COVID-19, which has not been shared with rest of the world? (iv) In whose interest is the current political economy of COVID-19, in every political economy there must be a party benefiting, could it be in furtherance of this benefit that COVID-19 emerged and is remaining? Why did China object to the terms of investigation of the WHO team, which arrived there for the initial investigation to discover the origin of this virus and insisted on its own terms? It is important in the interest of the global community to find the origin in order to be able to find the solution to COVID-19, because the symptoms seem to be enlarging by day, but the immediate known ones include; feverish conditions, cough and shortness of breath, body aches, nausea and diarrhea, anosmia (loss of smell), dizziness, blood clots, heart attack and organ failure. Few if any disease causes such a wide variety of symptoms (Ogunmupe, 2020 p18). It is a multisystem disease and a very deadly virus to be avoided.

\section{Accountability of States}

The dangerous spectrum of corona virus had been highlighted, scientific caution is the word in addressing it, what we are seeing is that political and economic pressures are taking the center stage above the precautions require to find solution to the risk of the pandemic. 
Lockdown of the cities and towns was aimed at buying time to develop a coherent mitigation strategies and tools for dealing with the situation. States should be able to subsidize the economic well-being of the citizens at a time like this, knowing that many people have been hindered from reaching their wealth creation points. This is when the accountability of many states is verified. It is bewildering that in the best of states, there are political considerations over economic and human welfare. COVID-19 economics reminds one of the postulation of a classical political philosopher, Marcus Tullius Cicero (106 -43 BC) that salus populi suprema lex' (let the welfare of the people be the supreme law) of the Government. This may not be prescription for states in Africa, and particularly sub-Saharan Africa where accountability of government is on vacation. Put differently, states in Africa are never accountable. Good governance should be the ideology of all states in the pandemic without which some states may be obliterated by corona virus dead. The African continent should be aware and be warned.

\section{Conclusion}

We set out to establish the theoretical, empirical and conceptual issues connected to COVID-19 in this study, we went on to validate that Covid-19 came within the spectrum of trade-war between the USA and China and that it must have been used as a weapon to break the economy of the other contestant. This was because though theoretically capitalism flaunts perfect competition as a principle of its operation, it however abhors competition and would rather seek to eliminate the competitor and operate as a monopoly. The war was initiated to reverse the enormous trade deficit incurred by the USA, however, the approach adopted by one of the parties was extremely undiplomatic and devoid of observing the WTO's guidelines regarding the protection of one's economy against the other.

China was objecting to the global community's quest to establish the origin of the virus and to look into the Wuhan Virology laboratory to ascertain element of leakage and the types of viruses housed therein. This would ascertain deliberate act of commission or otherwise from the laboratory. This was important because leakage from the Indian Union Carbide plant in December 1984 made its way into the adjoining towns, with great number of fatalities. The resistant of unfettered investigation to engagement in China's terms, raises suspicion of deliberate creation of the phenomenon, though this is yet to be proven beyond reasonable doubt.

Though two nation-states were engaged in the war, every other state which suffered the economic consequences of COVID-19 constituted collateral damages, as was the case during the first and second World-Wars, hence we tagged COVID-19 the third World war, given the number of states infected, and the number of causualties. Finally, we pursued the thesis that in order to address the situation of COVID-19, the global communities should come into alliance rather than competition to manufacture potent vaccine and be democratic in its distribution and usage. This is not without acknowledging the challenges that would be posed by the personality of the leaders of the two main countries at war. This would however become easier given that the leadership of one of the states in the conflict has since changed. It is important to form alliance, and be diplomatic in resolving this pandemic as earlier ones 
were resolved through global cooperation.

\section{References}

Adam, S. (2003). The Wealth of Nations-Introduction by Alan B. Krueger. New York: Bantam Classic.

Boylan, B. M., McBeath, J., \& Wang, B. (2021). US-China relations: Nationalism, the trade war, and COVID-19. Fudan Journal of the Humanities and Social Sciences, 14(1), 23-40.

Encyclopedia Britannica (1768) -World War1-killed, wounded, and missing retrieved 23 March 2021, 8,500,000 soldiers died, Civilian 13,000,000 Chicago: Merriam-Webster

Edward, R. C., Reich, M., Weisskopf, T. E. (1972). The Capitalist System- A Radical Analysis of American Society Engel Cliffs: Prentice-Hall.

Frank, E. O. (2015). Political Theory-Foundation of Social Organizations and Government-Uyo: Robert minder Publishers.

Harbulot, C. (2018). Lart de la guerre economique, editions: Versailles VA Press.

He, C., Mau, K., \& Xu, M. (2021). Trade Shocks and Firms Hiring Decisions (No. 001).

Igwe, O. (2005). Politics and Globe Dictionary (New Edition) Aba: Eagle Publishers.

Igwe, O. (2005). Politics and Globe Dictionary-Aba: Eagle Publishers.

McLean, I., \& McMillan, A. (2003) Oxford Concise Dictionary of Politics. OUP.

Ndiyo, N. A. (2005). Fundamental of Research in Behavioral Sciences and Humanities. Calabar: WUSEN Press.

New York Times. 'Trump Increases China Tariffs as Trade Deal Hangs in the Balance'. https://www.nytimes.com/2019/05/09/us/politics/china-trade-tariffs.html.'Accessed Feb.10,2021.

Owoye, O., \& Onafowora, O. A. (2020). United State-China Trade War and the Emergence of Global Covid-19 Pandemic Economia Internazionale/International Economics. Camera di Commercio Industrial Artigianato Agriccoltura di Genova, 73(4), 435-466.

Popkin, R. H., Stroll, A., \& Kelly, A. V. (1981). Philosophy Made Simple. London: Heinemann Books.

SARS -like corona virus found in wild bats: Scientist -The People Daily. 11 Sept. 2005, Retrieved 2007-08-16, accessed 27-08-2020.

Sodaro, M. J., Collinwood, D. W., Dickson, B. J., Klesner, J. L., \& Sisk, T. D (ed.) (2008) Comparative Politics-A Global Introduction, 3ed. New York: McGraw-Hill Higher Education

WHO. Summary of probable SARS cases with onset of illness from 1 November 2002 to 31 July 2003. www.int Retrieved 8 March 2018, accessed 27-08-2020.

Worldometers.info/coronavirus/c 'Countries where COVID-19 has spread' last updated: July 
20, 2021 accessed 19/07/21.

Zeng, T. (2003). The Last Defense Line: Concerns about the Loss of Chinese Genes'. People's Daily review, August 8, 2003 accessed 28-8-20.

Gagnon, J. E. (2018, November 1). Trump and Navarro's Mistaken Assumptions about Trade Deficits-Trade and Investment Policy Watch November 1, 2018 piie.com/blog/trade-and-invest (Peterson Institute for International Economics-1750 Massachusetts Av, NW, W-DC.

BBC online News (Jan. 2020) A Quick Guide to the US-China trade war, January 16, 2020.

Hass, R., \& Denmark, A. (2020). More pain than gain: How the US-China trade war hurt America. Brookings, August, 7.

Hass, R. \& Denmark, and A. (2020, August 7) Order from Chaos More than Gain: How the US-China trade war hurt America.

Ogunmupe, B. (2020, August 11) What we've learned about COVID 19' -The Guardian, Tuesday, August 11, 2020 p. 18 -A Nigeria Newspaper.

Lungu, A. (April, 2021) The US.-China Clash is about Ideology after all-Online publication -article accessed on the net on 19/7/21.

Chen, J. (2021). Trade War-Inestopedia.com accessed 21/7/21.

\section{Copyright Disclaimer}

Copyright for this article is retained by the author(s), with first publication rights granted to the journal.

This is an open-access article distributed under the terms and conditions of the Creative Commons Attribution license (http://creativecommons.org/licenses/by/4.0/). 